\title{
Comparative knowledge, attitudes, and practices regarding anthrax, brucellosis, and rabies in three districts of northern Tanzania
}

Christian Kiffner ${ }^{1 *}$ (D) Michelle Latzer ${ }^{2 \dagger}$, Ruby Vise ${ }^{3+}$, Hayley Benson ${ }^{4}$, Elizabeth Hammon ${ }^{5}$ and John Kioko ${ }^{1}$

\begin{abstract}
Background: Knowledge, attitudes, and practices (KAP) surveys regarding zoonotic diseases are crucial to understanding the extent of knowledge among citizens and for guiding health-related education programs.

Method: Employing a structured questionnaire, we interviewed residents $(n=388)$ in three districts of northern Tanzania (Karatu $n=128$, Monduli $n=114$, Babati $n=146$ ) to assess knowledge, attitudes and reported practices regarding three zoonotic diseases that occur in the region (anthrax, brucellosis, and rabies). We used generalized linear mixed effects models and multi-model inference to identify demographic correlates of knowledge.

Results: Proportional average district- and disease- specific knowledge scores ranged from 0.14-0.61. We found positive correlations between age and knowledge of symptoms, causes and treatments of anthrax (three districts), brucellosis (three districts), and rabies (one district). Gender, ethnic identity, formal education and ownership of livestock or dogs had variable effects on knowledge among the interviewed population. Risk perceptions regarding different diseases varied across districts and were positively correlated with knowledge of the specific diseases. Direct interactions with livestock and domestic dogs were reported to occur across all demographic groups, suggesting that most people living in rural settings of our study area are potentially exposed to zoonotic diseases. Behaviors which may favor transmission of specific pathogens (such as consumption of raw milk or meat) were occasionally reported and varied by district. Wildlife was generally regarded as negative or neutral with regard to overall veterinary and human health.

Conclusion: The combination of variable knowledge about zoonotic diseases in the three districts, reported occurrence of practices that are conducive to pathogen transmission, and previously documented circulation of pathogens causing anthrax, brucellosis and rabies in our study system, call for health education programs embedded in a holistic One Health approach.
\end{abstract}

Keywords: Anthrax, Brucellosis, Knowledge, attitudes, and practices, Rabies, Risk perception, Zoonotic disease

\footnotetext{
* Correspondence: ckiffne@gwdg.de

${ }^{\dagger}$ Michelle Latzer and Ruby Vise contributed equally to this work.

${ }^{1}$ Center for Wildlife Management Studies, The School For Field Studies, PO

Box 304, Karatu, Tanzania

Full list of author information is available at the end of the article
}

(c) The Author(s). 2019 Open Access This article is distributed under the terms of the Creative Commons Attribution 4.0 International License (http://creativecommons.org/licenses/by/4.0/), which permits unrestricted use, distribution, and reproduction in any medium, provided you give appropriate credit to the original author(s) and the source, provide a link to the Creative Commons license, and indicate if changes were made. The Creative Commons Public Domain Dedication waiver (http://creativecommons.org/publicdomain/zero/1.0/) applies to the data made available in this article, unless otherwise stated. 


\section{Background}

Zoonotic diseases are of major concern for public health and impose a considerable burden on national and global economies $[1,2]$. Compared to developed countries, veterinary and human health in developing countries are disproportionately affected by zoonotic pathogens because these countries are often located in the tropics and thus in areas of high pathogen species richness [3]. In addition, community dependence on livestock, high prevalence of bushmeat consumption, lack of food and water safety and security, and frequent interactions with wildlife may expose multiple sections of the human population to zoonotic pathogens [4-7]. Finally, a typically weak health infrastructure, insufficient training of medical and veterinary health workers, and inefficient cross-sectional collaboration between veterinarians, health practitioners and public health authorities frequently inhibit timely and appropriate diagnosis and treatment of zoonotic diseases $[8,9]$.

This general setting of potential exposure to zoonotic pathogens combined with limited medical diagnosis facilities and trained personnel in developing countries inevitably assigns substantial responsibility for disease prevention to individuals. Knowledge, attitude and practice studies (KAP) are suitable to assess the extent of knowledge among human populations and document current practices that possibly enhance risks for pathogen infections. Results from KAP studies are crucial to inform and guide public health education programs which attempt to close knowledge gaps and reduce the frequency of practices that potentially favor pathogen transmission [9-15]. Multiple demographic and other human related factors have been hypothesized to influence knowledge of a specific disease, and identifying particular subsets of the human population where knowledge is lacking, could greatly improve the efficacy of education programs [16]. For example, gender has been found to influence knowledge, with males often having greater knowledge about a specific disease [10]. Similarly, being potentially more exposed to a certain pathogen (e.g. living in an area with a high prevalence of a specific pathogen, or keeping animals that may be involved in the transmission of a specific pathogen), and having received formal education may also increase knowledge of a specific disease [10, 15, 17-19]. Beyond identifying knowledge gaps and documenting risky practices, KAP studies can further assess the general risk perception regarding different diseases among the local population, particularly if surveys target multiple diseases.

In this study we focused on three zoonotic diseases that are occasionally diagnosed from surveillance systems or research projects in humans living in rural northern Tanzania: anthrax, brucellosis, and rabies. Overall, these diseases may be considered 'neglected' diseases and their actual prevalence may be underreported in Tanzania due to challenges associated with integrated disease surveillance and response systems [20,21], occasional unspecific symptoms of zoonotic diseases (e.g. for brucellosis), and misdiagnoses of zoonotic diseases by medical practitioners [9].

Anthrax (causative agent: Bacillus anthracis) outbreaks have been relatively well documented in our study area. Anthrax outbreaks have caused substantial declines in wild animal populations in the past [22] and the disease is diagnosed among residents of Monduli district [23] and the neighboring Serengeti-Ngorongoro ecosystem [24]. From 2013 to 2016, the reported incidence rate was 7.88 cases / 100,000 persons in the Arusha region of northern Tanzania [23]. Despite being eradicated in some parts of the world, brucellosis (causative agent: Brucella spp.) occurs in wildlife, livestock, and humans of northern Tanzania $[9,12,19]$. In northern Tanzania, Brucella seroprevalence of up to $7.7 \%$ in humans and 3$4.6 \%$ in livestock has been documented [19]. Rabies (causative agent: rabies virus) circulates in Tanzania (mainly in domestic dog populations but frequent cases are diagnosed among the human and wildlife populations) despite substantial vaccination efforts in several parts of the country [25-28]. Seroprevalence of rabies in unvaccinated dogs in northern Tanzania can reach $31.6 \%$ [29].

We employed a comparative approach to assess knowledge, attitudes and practices regarding these diseases in three districts of northern Tanzania. The study area differs in major land-use forms and contact rates with wildlife species, and captures a variety of ethnic/cultural backgrounds. The main objectives were to assess and compare (1) the knowledge and correlates of knowledge regarding these three diseases, (2) the prevalence of practices that potentially increase infection risk, and (3) risk perceptions towards the three diseases. Finally, (4) we investigated interviewees' views towards wildlife with respect to veterinary and human health.

\section{Methods}

\section{Study area}

This interview-based study was carried out in the Karatu, Monduli and Babati districts of northern Tanzania (Fig. 1). The Karatu district is mainly located in the Mbulu highlands [30], which are semi-arid to humid [31]. The Ngorongoro Conservation Area (NCA) and Lake Manyara National Park (LMNP) are bordering village lands in this district which brings several wildlife species near farms of the predominant Iraqw people in the area [30]. The Iraqw are mostly small-holder agriculturalists, cultivating the land with maize, beans, pigeon peas, barley and wheat [32]. The Monduli district is east of the Karatu district and is located in the lowlands of 


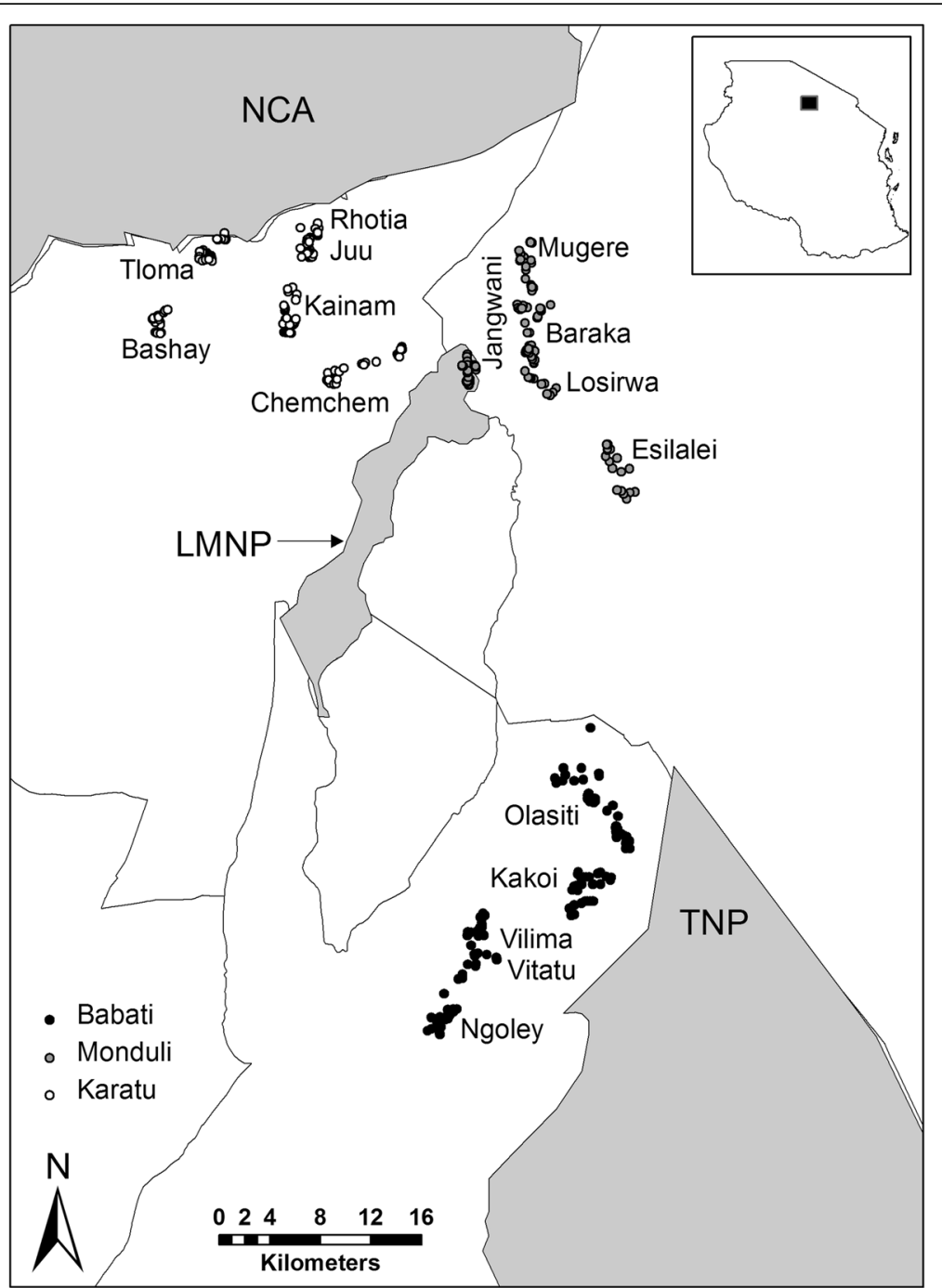

Fig. 1 Map of study area. Locations of household interviews in relation to the major protected areas (NCA = Ngorongoro Conservation Area; LMNP = Lake Manyara National Park; TNP = Tarangire National Park), Lake Manyara (LM) and district boundaries. Households in the village 'Jangwani' are not inside LMNP but at its border; the impression that they may be inside the national park may be due to inaccuracies of the protected area shapefile. The inset on the top right indicates the approximate location of the study area within Tanzania. Shapefiles for protected areas and district boundaries are available at: https://protectedplanet.net/country/TZ and https://gadm.org/download_country_v3.html

the Great Rift Valley [31]. This area is considered a semiarid landscape [30] and contains several conservation areas with high densities of wildlife: Lake Manyara National Park (LMNP), Manyara Ranch Conservancy (MR), and the Mto wa Mbu Game-Controlled Area (GCA) [33, 34]. Within this district we mainly sampled people residing in the rural areas around Mto wa Mbu town, which are primarily inhabited by Maasai pastoralists [30]. Within the Babati district, the study took place in villages within the Burunge Wildlife Management Area (WMA). These villages are located close to Tarangire National Park (TNP) and Manyara Ranch Conservancy (MR). The villages are part of the Burunge Wildlife Management Area and are thus in proximity to areas dedicated to wildlife conservation. This part of the
Babati district is a semi-arid area dominated by savannah habitats, and home to various ethnicities and agro-pastoral communities [30].

\section{Interviews}

Within each of the three districts, we chose either five (Karatu and Monduli) or four (Babati) villages. We chose villages for their relatively even distribution across the districts, sufficient number of households and accessibility and willingness of village heads to support the study. We conducted interviews using a predetermined and pretested questionnaire over the course of ten days in April 2017 and four days in November 2017. Prior to field work, translators and investigators went through 
the interview questions to clarify the meaning of each question and translated the questions to Swahili. In addition, we conducted test interviews with residents of Rhotia. We recruited translators from the Cultural Tourism Program in Mto Wa Mbu; all of them had previous research experience with interview-based studies in our study areas. We conducted all interviews in Swahili and translators translated responses immediately to English and responses were recorded in English.

We conducted interviews along 3-5 transects in each village. Approximately every $100 \mathrm{~m}$ along each transect, a trained translator (accompanied by one or two investigators) asked a member of a homestead to voluntarily participate in the survey. We only conducted interviews with one person over the age of 18 per household, after gaining verbal consent from the participant. In total, we conducted 388 interviews (Karatu district $n=128$; Monduli district $n=114$; Babati district $n=146$ ).

We first asked respondents if they were willing to take part in a 45-min survey on knowledge of zoonotic diseases in the area, prior to conducting the interview. We guaranteed participants anonymity as well as the right to stop the interview at any time, in accordance with protocols on rights of human subjects in research. Initially, we asked basic demographic information of the respondent (gender, age, highest level of education, ethnicity, and number of cattle/sheep\&goats/dogs owned). We recorded ethnicity as either the predominant ethnicity for each district (i.e. the numerical majority in our sample) or "other" (Karatu: Iraqw vs. other, Monduli: Maasai vs. other, and Babati: Maasai and Arusha combined vs. other). Despite considered different ethnicities, Arusha and Maasai share a common language, a primarily pastoralist lifestyle and many other cultural similarities. We are aware that this may constitute an oversimplification of the ethnic background of interviewees. However, given the diversity of ethnic backgrounds in our study area, we felt that this approach aligned with our major goal (i.e. to identify major determinants of knowledge such as living a primarily pastoralist vs. a primarily farming lifestyle) while ensuring sufficient degrees of freedom in the models.

In line with previous KAP studies [10], we then asked questions that assessed the respondents' knowledge regarding three zoonotic diseases: anthrax, brucellosis, and rabies. We first asked interviewees if they had heard about this disease. If interviewees had heard about the disease, we asked them whether this disease affect human and/or animals, what kind of symptoms may be present, how this disease can be transmitted, what kind of treatment should be used if a person or animal is infected, if infected persons should consult a medical doctor, and how transmission of this disease can be prevented (Additional file 1: Table S1).

After completing the interviews, responses were jointly assessed and transformed into knowledge points by the same two investigators against the stated criteria outlined in Table 1.

In addition to questions with regards to knowledge about the three diseases, we asked specific questions about practices that potentially enhance pathogen transmission and about demographic at-risk groups. For example, we asked which demographic groups in a household were responsible for livestock and dog handling. In addition, we asked interviewees about how they prepare or consume milk and meat because raw consumption of these animal products may increase pathogen infection risk (e.g. for brucellosis). Additionally, we asked interviewees whether the co-existence with wildlife generally increases, decreases or does not affect the health of livestock and people. At the end of the interview, we asked respondents to rank each disease in accordance to their perceived danger for human and livestock health; the lowest ranked disease embodied the most perceived danger.

\section{Data analyses}

The relative knowledge of each disease was assessed based on the number of obtained knowledge points (i.e. points awarded to answers according to criteria in Table 1) relative to the maximum achievable points for the corresponding disease (anthrax: 10 points; brucellosis: 10 points; rabies: 8 points). ML and RV carefully and jointly read through all answers and assigned knowledge points according to the criteria provided in Table 1.

Because interviewees in the three districts differed considerably in terms of socio-demographic structure, we analyzed data separately for each district and disease. To identify which demographic variables (ethnicity, gender, age, level of education, livestock ownership, dog ownership) were associated with the level of knowledge, we used a generalized linear mixed model with binomial error distribution, using the lme package implemented in the software $\mathrm{R}[38,39]$. Because the level of knowledge was assessed as proportion (achieved knowledge points / maximum number of achievable points), analyzing the data with linear regression models is not appropriate [40]. To avoid introducing a subjective knowledge threshold, we specified our target variable "knowledge" for each disease as a two-column variable whereas the first column contains the "achieved" points (i.e. successes) and the second column the "missed" points (i.e. failures); columns for successes and failures were combined using the cbind function [40]. Therefore, our model estimates the influence of explanatory variables on the relative knowledge about a specific disease in a logistic regression framework. To account for clustering of interviews (i.e. responses from interviewees from one village may not entirely be independent), we included a random effect for each village. Prior to model fitting, pairwise correlations across explanatory variables were 
Table 1 Description of symptoms, causes, treatments, and prevention methods for anthrax, brucellosis, and rabies in humans

\begin{tabular}{|c|c|c|c|c|}
\hline Disease & Symptoms & Causes & Treatment & Prevention \\
\hline Anthrax & $\begin{array}{l}\text { Small blisters or itchy bumps; } \\
\text { Painless ulcer after blister; } \\
\text { High fever/chills; } \\
\text { Chest pain; } \\
\text { Cough; } \\
\text { Headache; } \\
\text { Confusion/dizziness; } \\
\text { Fatigue; } \\
\text { Aches; } \\
\text { Diarrhea; } \\
\text { Stomach pain/swelling }\end{array}$ & $\begin{array}{l}\text { Inhalation of dust from } \\
\text { animal hide or hair } \\
\text { Consumption of undercooked, } \\
\text { infected meat; } \\
\text { Skin to open wound contact }\end{array}$ & $\begin{array}{l}\text { Seek medical care as } \\
\text { quickly as possible; } \\
\text { Antibiotics are routine } \\
\text { treatment }\end{array}$ & $\begin{array}{l}\text { Do not consume } \\
\text { undercooked meat; } \\
\text { Do not touch animal carcasses; } \\
\text { Vaccines for humans and } \\
\text { animals available }\end{array}$ \\
\hline $\begin{array}{l}\text { Anthrax scoring } \\
\text { (max. of } 10 \text { points) }\end{array}$ & $\begin{array}{l}0=0 \text { points } \\
1-2 \text { correct }=1 \text { point } \\
3 \text { or above correct }=2 \text { points } \\
\text { Observed in humans or } \\
\text { animals: } \\
\text { None }=0 \text { points } \\
\text { Humans }=1 \text { point } \\
\text { Animals }=1 \text { point } \\
\text { Both }=2 \text { points }\end{array}$ & $\begin{array}{l}0=0 \text { points } \\
1-2 \text { correct }=1 \text { point } \\
3 \text { or above correct }=2 \text { points }\end{array}$ & $\begin{array}{l}0=0 \text { points } \\
1 \text { correct }=1 \text { point } \\
\text { Seek professional help: } \\
\text { Yes }=1 \text { point } \\
\text { No }=0 \text { points }\end{array}$ & $\begin{array}{l}\text { None }=0 \text { points } \\
1 \text { correct }=1 \text { point }\end{array}$ \\
\hline Brucellosis & $\begin{array}{l}\text { Fever of unknown origin; } \\
\text { Nonspecific and assorted } \\
\text { symptoms such as: sweats, } \\
\text { weight loss, depression, } \\
\text { arthralgias, fatigue, malaise; } \\
\text { Can occur in any organ system } \\
\text { of the body }\end{array}$ & $\begin{array}{l}\text { Consuming unpasteurized milk } \\
\text { or meat from infected animals; } \\
\text { Direct contact with secretions } \\
\text { of infected animals; } \\
\text { Breathing in brucellosis bacteria }\end{array}$ & $\begin{array}{l}\text { Seek immediate } \\
\text { consultation from doctor; } \\
\text { Antibiotic treatment } \\
\text { regime }\end{array}$ & $\begin{array}{l}\text { Boiling milk before } \\
\text { consumption; } \\
\text { Vaccination of livestock; } \\
\text { Protection from dead animal/ } \\
\text { livestock tissue }\end{array}$ \\
\hline $\begin{array}{l}\text { Brucellosis scoring } \\
\text { (max. of } 10 \text { points) }\end{array}$ & $\begin{array}{l}0=0 \text { points } \\
1-2 \text { correct }=1 \text { point } \\
3 \text { or above correct }=2 \text { points } \\
\text { Observed in humans } \\
\text { or animals: } \\
\text { None }=0 \text { points } \\
\text { Humans }=1 \text { point } \\
\text { Animals }=1 \text { point } \\
\text { Both }=2 \text { points }\end{array}$ & $\begin{array}{l}0=0 \text { points } \\
1 \text { correct }=1 \text { point } \\
2 \text { or above correct }=2 \text { points }\end{array}$ & $\begin{array}{l}0=0 \text { points } \\
1 \text { correct }=1 \text { point } \\
\text { Seek professional help } \\
\text { Yes }=1 \text { point } \\
\text { No }=0 \text { points }\end{array}$ & $\begin{array}{l}\text { None }=0 \text { points } \\
1 \text { correct }=1 \text { point } \\
2 \text { or above correct }=2 \text { points }\end{array}$ \\
\hline Rabies & $\begin{array}{l}\text { Flu-like symptoms; } \\
\text { Fever; } \\
\text { Headache; } \\
\text { Fatigue/weakness; } \\
\text { Acute neurologic } \\
\text { syndrome; } \\
\text { Coma }\end{array}$ & $\begin{array}{l}\text { Rabies Virus; } \\
\text { In almost all cases virus is } \\
\text { transmitted via bite of } \\
\text { infected animal }\end{array}$ & $\begin{array}{l}\text { Post exposure vaccines; } \\
\text { Immune globulin }\end{array}$ & $\begin{array}{l}\text { Vaccination of domestic pets; } \\
\text { No direct contact/handling } \\
\text { of wild animals }\end{array}$ \\
\hline $\begin{array}{l}\text { Rabies scoring } \\
\text { (max. of } 8 \text { points) }\end{array}$ & $\begin{array}{l}0-1=0 \text { points } \\
2+\text { correct }=1 \text { point } \\
\text { Observed in Humans or } \\
\text { Animals: } \\
\text { None }=0 \text { points } \\
\text { Humans }=1 \text { point } \\
\text { Animals }=1 \text { point } \\
\text { Both }=2 \text { points }\end{array}$ & $\begin{array}{l}\text { Contact with infected } \\
\text { animal = } 1 \text { point }\end{array}$ & $\begin{array}{l}\text { Human: seek professional } \\
\text { treatment = } 1 \text { point } \\
\text { Animal: kill infected } \\
\text { animal = } 1 \text { point }\end{array}$ & $\begin{array}{l}\text { Vaccination or no contact with } \\
\text { (infected/symptomatic) } \\
\text { animals = } 1 \text { point }\end{array}$ \\
\hline
\end{tabular}

Below the row outlining symptoms, causes and prevention methods, we report the applied scoring system for each category. We assigned scores according to the provided answers and specific disease information provided by Centers For Disease Control and Prevention [35-37]

assessed using the corrplot package [41]; since none of the correlation exceeded the 0.7 collinearity threshold (Additional file 2: Figure S2), we included all variables in our models [42]. Due to the high number of a priori hypotheses (gender, age, level of education, ethnicity, livestock ownership for anthrax, and dog ownership for rabies) we first fitted a full model (including all hypothesized variables) and standardized regression coefficients (numeric variables with more than two values were rescaled to a mean of 0 and a standard deviation of 0.5 ; binary variables were rescaled to have a mean of 0 and a difference of 1 between their two categories) using the arm package [43]. We then ran all possible permutations of variable combinations (only using additive linear effects) using the MumIn package. Since multiple models had similar model selection support, we model averaged regression coefficients of models within $\Delta$-AICc- 
values $\leq 6$ using the full average method [44-46]. Model selection tables can be found in the electronic appendix (Additional file 3: Table S2). To predict model outcomes, we calculated odds ratios (exponent of regression coefficients) which describe the relative change in knowledge in response to the corresponding explanatory variable i.e., the relative change in knowledge compared to the reference level for categorical variables and the relative change in knowledge when continuous variables change by one unit (note that variables were standardized and the odds ratios thus relate to the mean of the explanatory variable). In line with information-theory we assessed variables based on relative variable importance (computed in the
MumIn package) and confidence intervals of regression estimates.

To describe reported practices in relation to zoonotic disease infection risk and at-risk groups, we provide proportions of responses for each district. Proportions were based on the interview sample size in each district (Karatu district $n=128$; Monduli district $n=114$; Babati district $n=146$ ); in case respondents answered multiple practices or at-risk groups, we created new categories for these answers. We used a Kruskal Wallis anova to test for significant differences in risk perception towards the three diseases and Kendall's correlation test to assess associations between relative knowledge and risk perception of the three diseases.

Table 2 Socio-demographic characteristics of interviewees in the three surveyed districts of northern Tanzania

\begin{tabular}{|c|c|c|c|c|c|c|c|c|}
\hline & Karatu (\#) & Karatu (prop.) & & Monduli (\#) & Monduli (prop.) & & Babati (\#) & Babati (prop.) \\
\hline Households & 128 & & & 114 & & & 146 & \\
\hline \multicolumn{9}{|l|}{ Gender } \\
\hline Male & 67 & 0.52 & & 67 & 0.59 & & 50 & 0.34 \\
\hline \multirow[t]{2}{*}{ Female } & 61 & 0.48 & & 47 & 0.41 & & 96 & 0.66 \\
\hline & Mean & Range & & Mean & Range & & Mean & Range \\
\hline Age & 42 & $18-88$ & & 36 & $18-74$ & & 39 & $18-85$ \\
\hline Ethnicity & (\#) & (prop.) & Ethnicity & (\#) & (prop.) & Ethnicity & $(\#)$ & (prop.) \\
\hline Iraqw & 112 & 0.88 & Maasai & 67 & 0.59 & Maasai & 54 & 0.37 \\
\hline Other & 16 & 0.13 & Other & 47 & 0.41 & Other & 92 & 0.63 \\
\hline \multicolumn{9}{|l|}{ Education } \\
\hline None & 13 & 0.10 & & 25 & 0.22 & & 25 & 0.17 \\
\hline Primary & 88 & 0.69 & & 61 & 0.54 & & 80 & 0.55 \\
\hline Secondary and above & 27 & 0.21 & & 28 & 0.25 & & 41 & 0.28 \\
\hline \multicolumn{9}{|l|}{ Livestock ownership } \\
\hline Yes & 100 & 0.78 & & 80 & 0.70 & & 112 & 0.77 \\
\hline \multirow[t]{2}{*}{ No } & 28 & 0.22 & & 34 & 0.30 & & 34 & 0.23 \\
\hline & Mean & Range & & Mean & Range & & Mean & Range \\
\hline Number of cattle & 3 & $0-50$ & & 20 & $0-320$ & & 13 & $0-200$ \\
\hline Number of goats \& sheep & 4 & $0-35$ & & 38 & $0-400$ & & 20 & $0-300$ \\
\hline Dog ownership & (\#) & (prop.) & & (\#) & (prop.) & & $(\#)$ & (prop.) \\
\hline Yes & 73 & 057 & & 71 & 0.62 & & 95 & 0.65 \\
\hline No & 55 & 0.43 & & 43 & 0.38 & & 51 & 0.35 \\
\hline Villages & Households & (prop.) & Villages & Households & (prop.) & Villages & Households & (prop) \\
\hline Bashay & 21 & 0.16 & Baraka & 17 & 0.15 & Kakoi & 33 & 0.23 \\
\hline Chem Chem & 26 & 0.20 & Esilalei & 17 & 0.15 & Ngoley & 40 & 0.27 \\
\hline Rhotia Juu & 29 & 0.23 & Jangwani & 29 & 0.25 & Olasiti & 36 & 0.25 \\
\hline Rhotia Kainam & 27 & 0.21 & Losirwa & 28 & 0.25 & Vilima Vitatu & 37 & 0.25 \\
\hline Tloma & 25 & 0.20 & Mugere & 23 & 0.20 & & & \\
\hline
\end{tabular}

Frequencies for each category are given in absolute (\#) and proportional (prop.) terms 


\section{Results}

\section{Socio-economic characteristics of the interviewees}

We surveyed a total of 388 households in the districts of Karatu ( $n=128$ in five villages), Monduli ( $n=114$ in five villages), and Babati ( $n=146$ in four villages). In each village, we sampled between 17 and 40 households (Table 2). Overall, gender of respondents was relatively evenly distributed (Table 2). Proportionally, respondents in Karatu district were primarily of the Iraqw ethnicity (0.88), and were typically small-scale farmers. In Babati, and particularly in Monduli districts, a substantial share of the interviewees were Maasai $(0.59$ and 0.37 , respectively) and lived a mainly pastoralist lifestyle (Table 2).

Primary education was most common in each district, followed by secondary (and above) education but a substantial fraction of the interviewees $(0.10-0.20$ of respondents) had not received any formal education. In terms of dog and livestock ownership, interviewees in the three districts appeared similar, but owing to the

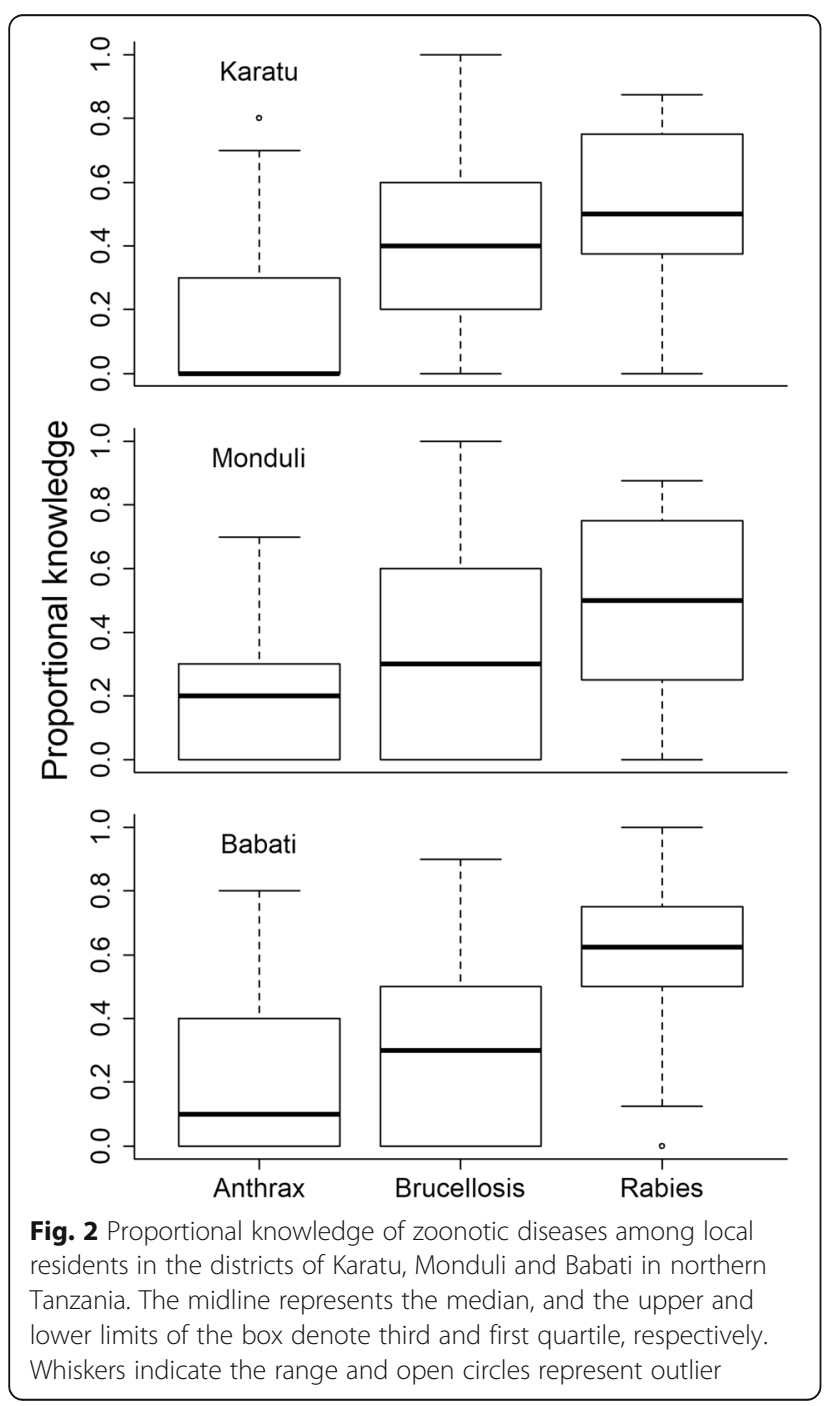

predominant pastoralists' ethnicities in Monduli and Babati, interviewees in these two districts usually had larger livestock herds compared to people residing in Karatu district (Table 2).

\section{Knowledge about zoonotic diseases}

Knowledge regarding anthrax, brucellosis, and rabies varied across districts (Fig. 2). In Karatu, respondents were most informed about rabies, followed by brucellosis, and least informed about anthrax. Interviewees in the district of Monduli also had greater knowledge of brucellosis, and rabies compared to anthrax. Respondents in Babati had greater knowledge of rabies, and anthrax than other districts, but comparatively little knowledge on brucellosis (Fig. 2).

According to generalized linear mixed models and subsequent model selection, age [based on relative variable importance (RVI) and confidence intervals non-overlapping with zero] was the major influential factor affecting anthrax knowledge in all three districts (Table 3). Regarding anthrax, the odds of scoring more points increased by $2.02-$ 2.61 times per year of life (Table 3; please note that age was centered; i.e. the average age was scaled to zero). Gender was found to influence anthrax knowledge in both Karatu and Babati districts. In males the odds for scoring more knowledge points were 1.89-2.28 greater than for females. In Karatu, Iraqw respondents had less knowledge of anthrax than other ethnicities residing in the area. Formal education was positively associated with knowledge about anthrax, but confidence intervals of the regression coefficients overlapped with zero which implies that this relationship was not consistent or very strong (Table 3).

Knowledge pertaining to brucellosis was positively associated with age of respondents in all three districts. For the districts Monduli and Babati, ethnicity was also found to be an important determinant of knowledge, with members of other ethnicities knowing relatively more about rabies compared to interviewees of Maasai (Monduli) or Maasai and Arusha (Babati) ethnic identity (Table 3).

In Karatu district, gender explained some differences in knowledge about rabies. In male respondents, the odds for scoring greater knowledge points were 1.76 times greater compared to female interviewees. In this district, age positively influenced respondent's knowledge as well. Among respondents in Monduli, interviewees with a primary education or secondary education had about two times greater odds to score more knowledge points compared to interviewees without formal education. In the Babati district, none of the regression estimates were strongly associated with knowledge of rabies (Table 3).

Practices and risk factors related to zoonotic diseases Overall, all demographic groups within a household reportedly took care of livestock and dogs (Fig. 3) but the 


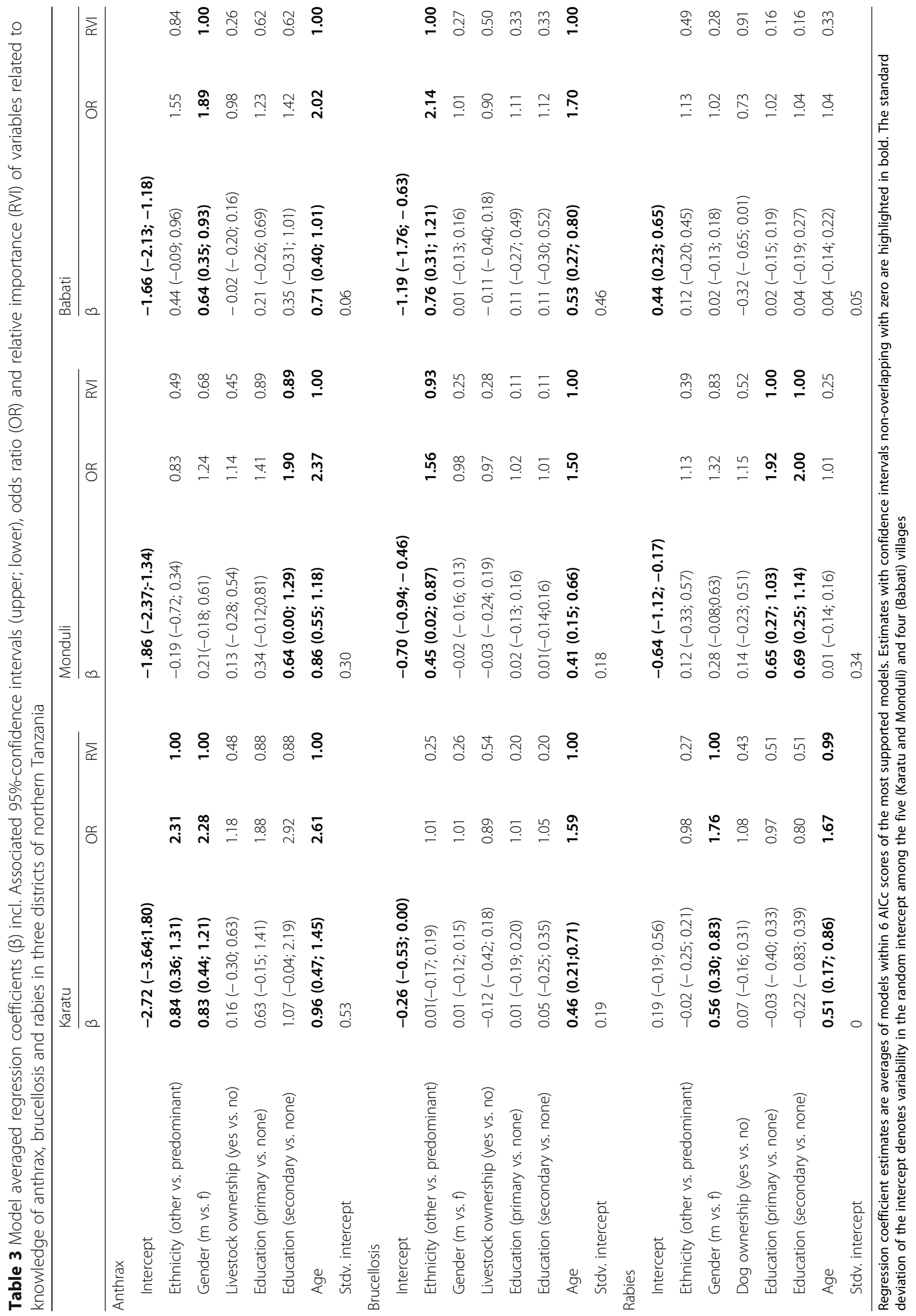



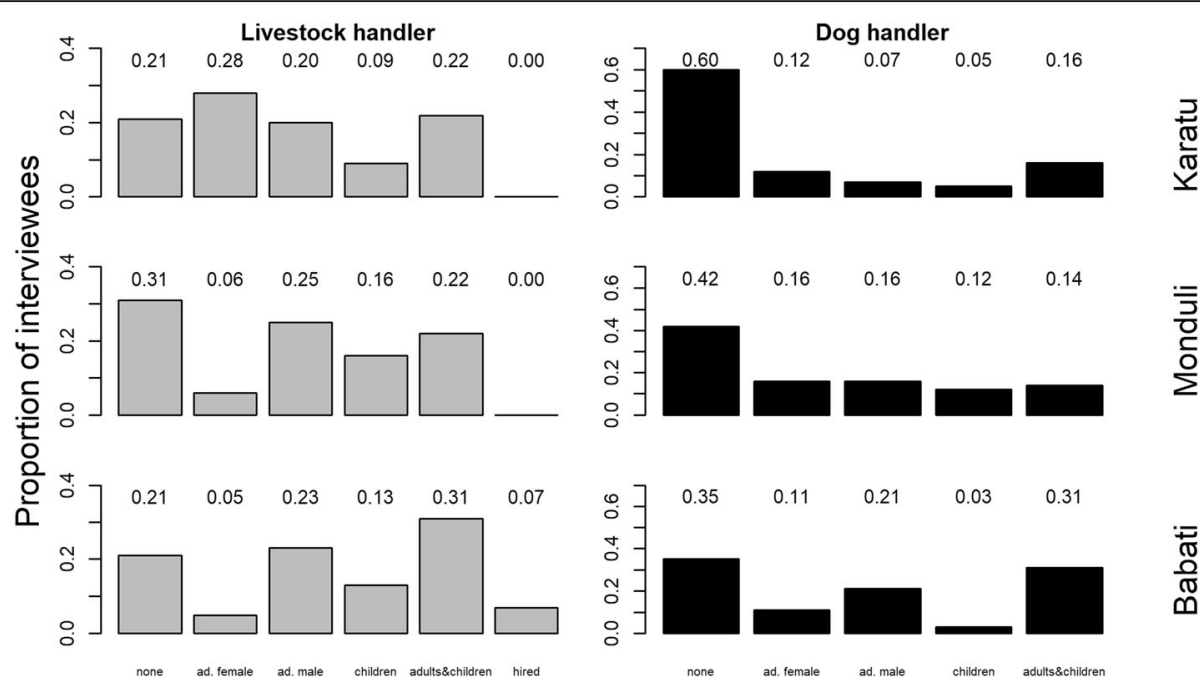

Fig. 3 Reported proportion of demographic groups (ad. = adult) responsible for livestock and dog handling among interviewed households in three districts (Karatu, Monduli, and Babati) of northern Tanzania. Scores denote the exact proportion of each bar category

main demographic group differed across districts. In Karatu, adult females were often mainly responsible for livestock (0.28 of respondents), whereas in Monduli (0.06) and Babati (0.05), adult females were rarely solely handling livestock. Children were also reported (adults and children combined: 0.31-0.44) to handle livestock in all districts. Similarly, dog handling was reportedly carried out by all demographic groups, including children (Fig. 3); children were major dog handler (children and adults \& children combined) in a fifth to a third (0.21-0.36) of all households. Dog ownership in Monduli and Babati was also more prevalent compared to Karatu (Fig. 3; Table 2).
The majority of interviewees in all three districts reported that milk (Karatu: 0.99; Monduli 0.77; Babati: 0.91) and meat (Karatu: 0.98; Monduli 0.88; Babati:0.94) were always boiled or cooked before consumption (Fig. 4). However, particularly in the districts of Monduli and Babati, a notable proportion of respondents reported consuming raw milk (Karatu: 0.01; Monduli 0.23; Babati: 0.09) and raw meat (Karatu: 0.01; Monduli 0.12; Babati: 0.06).

\section{Attitudes towards zoonotic diseases}

Interviewees in Monduli and Babati districts frequently ranked rabies as the most dangerous disease, whereas
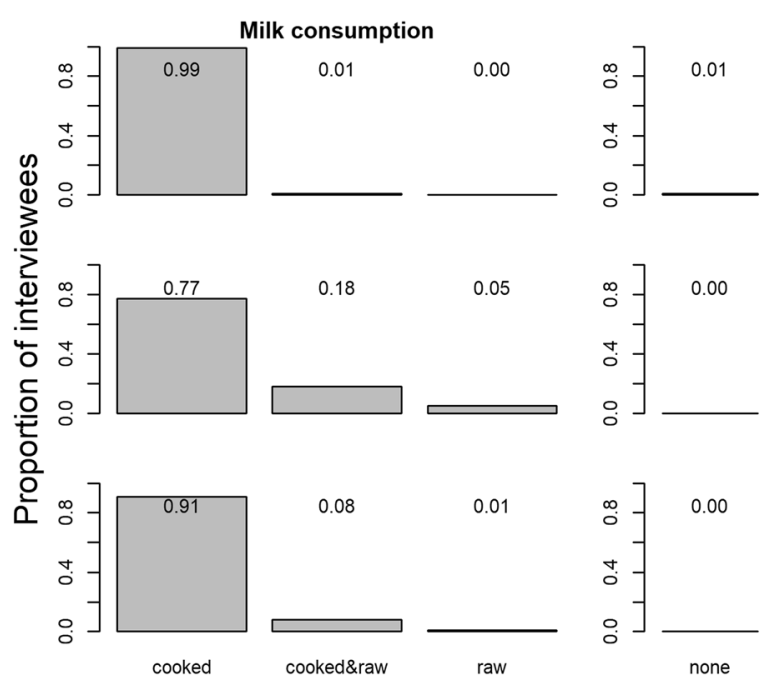

Meat consumption

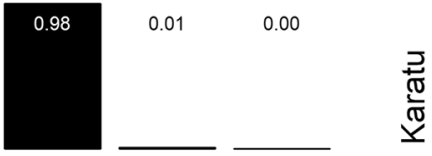

$\frac{7}{\frac{\pi}{0}}$

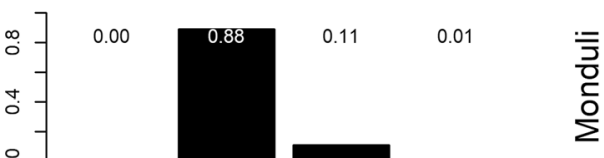

$\bar{y}$
$\frac{0}{0}$
을
$\frac{1}{\sqrt{0}}$
$\frac{0}{0}$

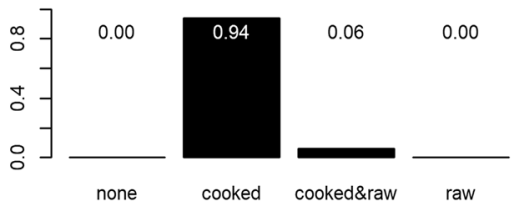

Fig. 4 Reported preparation of milk and meat before consumption as reported by households in three districts (Karatu, Monduli, and Babati) of northern Tanzania. Scores denote the exact proportion of each bar category 


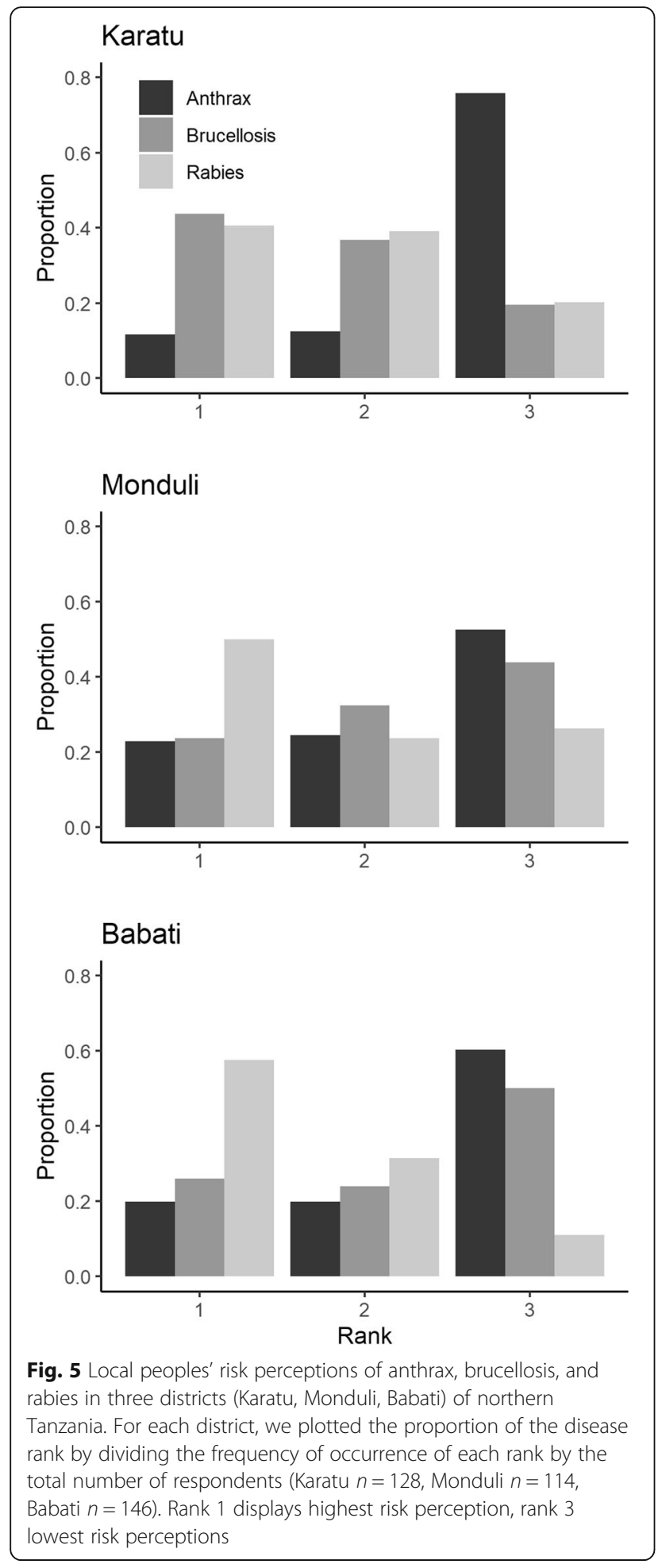

interviewees in Karatu district rated brucellosis (closely followed by rabies) as a major threat to human and livestock health. Anthrax was consistently rated as least dangerous disease in all three districts (Fig. 5). Within all three districts, rankings of the three diseases were significantly different (Kruskal Wallis $\mathrm{X}^{2}>25$; $\mathrm{df}=2 ; p<$
0.001 for comparisons within districts). In all three districts, risk ranks were significantly (all $p \leq 0.001$ ) correlated with the proportional knowledge of each disease (Karatu: tau $=-0.38, n=384$; Monduli: tau $=-0.36, n=$ 342; Babati: tau $=-0.39, n=438$ ). Given our risk scale ( 1 = most dangerous; 3 = least dangerous), people with greater knowledge about a specific disease tended to perceive it as more dangerous.

Attitudes towards wildlife in relation to zoonotic diseases In all three districts, a large share of local people (Karatu: 0.47; Monduli: 0.43; Babati 0.72) expressed that wildlife had an overall negative influence on human and livestock health (Fig. 6). However, large proportions of the interviewees, particularly in Karatu and Monduli, mentioned that wildlife had a neutral (Karatu: 0.40; Monduli: 0.40; Babati: 0.24) or even a positive effect (Karatu: 0.13; Monduli: 0.17; Babati: 0.04) on human and livestock health.

\section{Discussion}

Our KAP survey across three districts of northern Tanzania revealed that (1) relative knowledge about causes, symptoms, initial treatments and prevention methods regarding three zoonotic diseases (anthrax, brucellosis, and rabies) was very variable. Interestingly, (2) knowledge about specific diseases varied across districts, and (3) socio-demographic correlates of knowledge were rather variable in direction and strength with the exception of the frequently observed positive association between interviewee's age and knowledge regarding knowledge of anthrax (all three districts), brucellosis (all

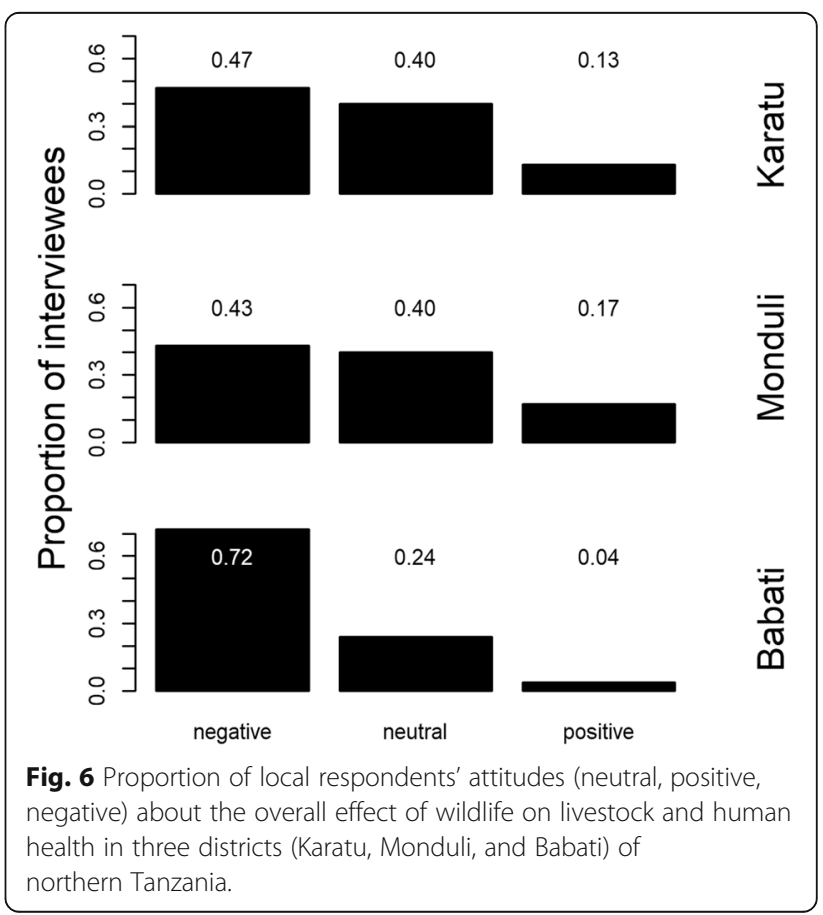


three districts), and rabies (Karatu district). In addition, our survey revealed that (4) practices such as drinking raw milk and eating raw meat are practiced among a sizeable portion (reported proportional raw consumption in the three districts ranged from $0.01-0.23$ for milk and 0.01 to 0.12 for meat) of the surveyed population, particularly in the districts with a greater share of ethnicities practicing pastoralist lifestyles. Finally, we show that (5) risk perceptions of diseases were positively and relatively consistently correlated with knowledge regarding specific diseases in each district.

\section{Knowledge and practices related to zoonotic diseases}

Limited level of knowledge regarding zoonotic diseases, both among the rural population [10] and among medical practitioners [9], and limited access to treatments or post exposure prophylaxis [47], constitute favorable conditions for zoonotic pathogen transmission. Beyond appropriate public health laws, education, and individual behavior can possibly minimize the transmission of infectious diseases. Identifying knowledge gaps in human populations can thus be helpful $[48,49]$. KAP studies are useful for identifying such knowledge gaps across landscapes and different demographic groups of the public, yet are associated with some level of uncertainty and potential bias. Our comparative approach required standardization in the interview process and the consistent scoring of answers according to pre-defined criteria. The trade-off for this standardization may be that we have underestimated actual knowledge due to possible language barriers (e.g. Swahili may not be the first language for all interviewees) and little efforts by interviewers to prompt more answers.

Despite these possible limitations, interviewees knew comparatively little about anthrax, with slightly greater knowledge scores achieved in the districts of Monduli and Babati (Table 3). Greater knowledge in Monduli and Babati can possibly be explained by historic anthrax outbreaks in Lake Manyara National Park (which is located in Monduli district, and borders Babati district) during the 1970s and 1980s [22, 50]. Importantly, Monduli district is still considered a high risk area for anthrax, with multiple instances of mainly cutaneous anthrax cases diagnosed in health facilities in this district [23]. During the dry season of 2018 an anthrax outbreak occurred in Babati district, mainly at the eastern shore of Lake Manyara, with numerous verified anthrax cases in wildebeest Connochaetes taurinus and other wildlife species (C. Laizer, pers. comm). In Monduli, and possibly also in Babati, the consumption of bushmeat is relatively common across large fractions of local residents [51], which may be a risk factor for exposure to anthrax given the high prevalence of $B$. anthracis in samples of wildlife species that are usually consumed by humans [23]. Indeed, anthrax infection risk seems to be particularly high in demographic groups that are frequently involved in handling animals (milking, slaughtering, skinning) [52].

Similar to other studies $[10,53]$, the findings of age being a key determinant of knowledge and spatially heterogeneous distribution of knowledge, provides some circumstantial evidence that knowledge about specific diseases is possibly affected by experience of past disease outbreaks and interventions in a given area. However, this hypothesis is difficult to test given the scarcity of reliable and comparative data on actual disease prevalence in space and time. Alternatively, the effect of age may merely indicate greater accumulated knowledge over a person's lifespan (e.g. greater likelihood of exposure to public health information campaigns). Regardless of the underlying reasons for age being positively correlated with increased knowledge, this relationship supports the need for increased health education covering zoonoses among younger generations.

Seemingly, greater potential exposure to a zoonotic disease did not necessarily equate to greater knowledge in other cases. For example, the primarily pastoralist ethnicities in Monduli and Babati knew less about brucellosis compared to other non-primarily pastoralist ethnicities (Table 3). However, these relationships may also have been blurred by actual differences in brucellosis prevalence and possibly also by language barriers.

Formal education only had limited effects on knowledge regarding zoonotic diseases. An exception may be Monduli district, where education was positively associated with knowledge for anthrax and rabies. However, given the correlative nature of our study, it is not possible to accredit greater knowledge to specific education regarding zoonotic diseases in schools per se. To our knowledge, neither primary nor O-levels school syllabi in Tanzania explicitly cover aspects of the three diseases. Similarly, we are not aware of specific information campaigns on these diseases in our study area. Yet, before employing information campaigns in the school system or outside of formal education systems, it may be instrumental to formally assess the effectiveness of these education programs.

Because other hypothesized predictors were inconsistently related to knowledge regarding the three diseases and knowledge was occasionally lower in high risk groups compared to people possibly not as exposed, we suggest that a proactive educating system in the frame of a holistic One Health approach should be implemented in our study area [52]. Such education should particularly target individuals with elevated exposure to zoonotic diseases including children who often handle livestock and dogs in our study area and are thus exposed to potential infection. To some extent, variable exposure to specific pathogens 
reflects differences in cultural practices, and ethnicspecific gender roles $[19,52]$, which can be used to better identify specific risk groups. In light of frequent interactions between children, livestock and dogs (and thus potential exposure of children to associated zoonotic pathogens), it may be worthwhile to consider including basic aspects of zoonotic risk prevention in primary school education.

\section{Attitudes towards zoonotic diseases and risk perception} Unfortunately, there is only limited information (actual exposure risk and associated morbidity) about the relative importance of each disease in terms of public health in the region which prevents us to ascertain an objective disease risk ranking. In addition, the question was asked in a general sense which could have caused variable interpretation of the question among interviewees. Yet, considering a near $100 \%$ fatality rate in humans (if no post-exposure prophylaxis is administered), rabies may objectively be the most dangerous of the considered diseases [28, 35]. Indeed, a great proportion of respondents in Monduli and Babati rated rabies as the most dangerous disease (Fig. 5). Rabies prevalence is often underestimated in northern Tanzania $[28,54]$ and incidences may substantially be underreported. Apart from small-scale vaccination trials in Babati district [55], we are not aware of large scale dog (and cat) vaccination projects in the three studied districts. In light of the considerable effectiveness of mass vaccinations of domestic dogs and cats in reducing rabies [25, 27], this option should be jointly considered by public health authorities, local communities and international organizations [56] .

\section{Attitudes towards wildlife in relation to zoonotic diseases} Our interview data (Fig. 6) largely reflect overall negative perceptions regarding wildlife in this study area [57] and suggest that - with regard to human and veterinary health - the majority of rural people mainly perceive costs associated with wildlife, and few people consider wildlife species as beneficial for human and veterinarian health. Beyond the potential for pathogen transmission, large wildlife species cause direct and indirect costs to rural population in northern Tanzania [57]. Therefore, beyond improved education on zoonotic diseases, integrated "One Health" efforts need to strengthen the veterinary and medical infrastructure (hospitals and veterinary offices; reasonable transport options to health facilities; appropriate diagnosis tools and methods), services (e.g. preventive vaccination programs; affordable or free consultation at hospitals and veterinary district offices), and effective co-operation across the human health, veterinary, and wildlife sector. In turn, such investments in public health may additionally improve wildlife conservation efforts since improvements in veterinary health services could be associated with reductions in the severity of human-wildlife conflicts, because healthier livestock are possibly less prone to attacks by large carnivores [58].

\section{Conclusion}

This KAP survey covering three diseases and spanning three districts highlights substantial knowledge gaps among the rural population in northern Tanzania. Proactively educating rural populations (i.e. before the occurrence of disease outbreaks), particularly targeting ethnic and demographic groups with elevated exposure risk to specific pathogens, could be a valuable tool to minimize transmission of zoonotic pathogens. Although clear evidence that education effectively reduces infection risk is often lacking [59], we hypothesize that education could be cost-effective method to reduce infection risk.

\section{Supplementary information}

Supplementary information accompanies this paper at https://doi.org/10. 1186/s12889-019-7900-0

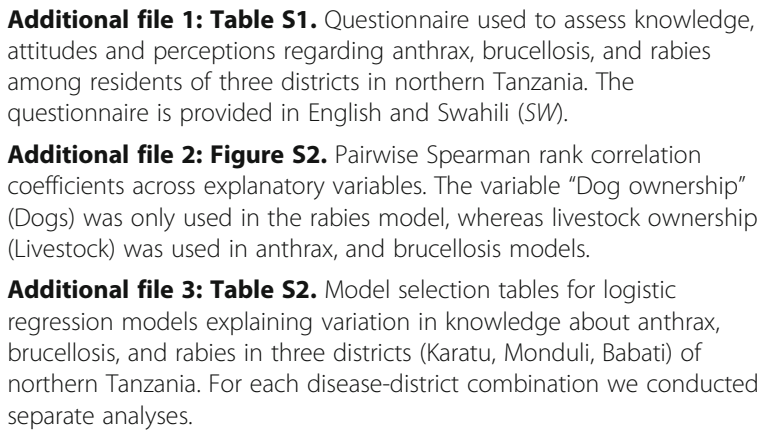

Additional file 1: Table S1. Questionnaire used to assess knowledge, attitudes and perceptions regarding anthrax, brucellosis, and rabies among residents of three districts in northern Tanzania. The questionnaire is provided in English and Swahili (SW).

Additional file 2: Figure S2. Pairwise Spearman rank correlation coefficients across explanatory variables. The variable "Dog ownership" (Dogs) was only used in the rabies model, whereas livestock ownership (Livestock) was used in anthrax, and brucellosis models.

Additional file 3: Table S2. Model selection tables for logistic regression models explaining variation in knowledge about anthrax, brucellosis, and rabies in three districts (Karatu, Monduli, Babati) of northern Tanzania. For each disease-district combination we conducted separate analyses.

\section{Abbreviations}

Ad: Adult; AICc: sample size corrected Akaike information criterion; GCA: Mto wa Mbu Game-Controlled Area; KAP: Knowledge, attitudes, and practices; LM: Lake Manyara; LMNP: Lake Manyara National Park; MR: Manyara Ranch Conservancy; NCA: Ngorongoro Conservation Area; TNP: Tarangire National Park

\section{Acknowledgements}

We thank all participating guides and SFS students who conducted the interviews. We sincerely thank all participating interviewees for their time and openness. J. Silaa kindly helped with the map. We sincerely thank F. Artress (Fame Africa) for providing a clinical perspective on zoonotic diseases and C. Laizer (Babati district) for information regarding the recent anthrax outbreak. We thank three reviewers for providing detailed feedback that helped to improve the manuscript.

\section{Authors' contributions}

All authors have read and approved the manuscript. CK: Planned and designed the study, analyzed and interpreted the data and wrote the manuscript. ML: conducted the interviews, managed and analyzed the data and revised the manuscript. RV: conducted the interviews, managed and analyzed the data and revised the manuscript. HB: conducted the interviews, managed and analyzed the data and revised the manuscript. EH: conducted the interviews, managed and analyzed the data and revised the manuscript. All authors read and approved the final manuscript. JK: Planned and designed the study and revised the manuscript. 


\section{Funding}

The authors did not receive specific funding for this research project.

\section{Availability of data and materials}

Data are publicly available and can be accessed at: https://datadryad.org/ stash/share/K_rGX39KB03BtFztEp9xUjUQ42kKFyzwLcydqx18Ntc.

\section{Ethics approval and consent to participate}

The protocol for this research was reviewed and approved by the Tanzanian Wildlife Research Institute (TAWIRI) and by "Tanzania Commission For Science and Technology" (COSTECH permits \# 2016-349-NA-2013-191 and 2017-288-ER-2013-191), the principal advisory organ relating to scientific research and technology development in Tanzania. COSTECH did not request further ethical reviews. However, in addition and prior to the start of the project, the research protocol was reviewed and exempted from further IRB review under the U.S. Code of Federal regulation title 45 public welfare part 46 protection of human subjects 46.101b (Type B, Category 2; IRB protocol number: TZ-02-17) because the interview process was solely geared towards assessing knowledge, attitudes and perceptions regarding zoonotic diseases and did not aim at gathering any personal medical information. We received supporting letters from Karatu, Monduli and Babati districts as well as consent from chairpersons of all 14 villages prior to the start of this study. Upon approaching potential interviewees, the purpose of the interview was explained, anonymity guaranteed (GPS coordinates of households will therefore not be published) and all participants expressed verbal consent.

\section{Consent for publication}

Not applicable.

\section{Competing interests}

The authors declare that they have no competing interests.

\section{Author details}

${ }^{1}$ Center for Wildlife Management Studies, The School For Field Studies, PO Box 304, Karatu, Tanzania. ${ }^{2}$ School of Public Health, College of Charleston, Charleston, SC 29401, USA. ${ }^{3}$ Department of Integrative Biology, Oregon State University, Corvallis, OR 97331, USA. ${ }^{4}$ College of Computer, Mathematics, and Natural Sciences, University of Maryland, College Park, MD 20742, USA.

${ }^{5}$ School of Nursing, Clemson University, Clemson, SC 29632, USA.

Received: 4 July 2019 Accepted: 5 November 2019

Published online: 03 December 2019

\section{References}

1. Binder S, Levitt AM, Sacks JJ, Hughes JM. Emerging infectious diseases: public health issues for the 21st century. Science (80- ). 1999;284(5418):1311-3.

2. Morens DM, Folkers GK, Fauci AS. The challenge of emerging and reemerging infectious diseases. Nature. 2004;430:242.

3. Guernier V, Hochberg ME, Guégan J-F. Ecology drives the worldwide distribution of human diseases. PLoS Biol. 2004;2(6):e141.

4. Barua M, Bhaqwat SA, Jadhav S. The hidden dimensions of human-wildlife conflict: health impacts, opportunity and transaction costs. Biol Conserv. 2012;157:309-16.

5. Clifford DL, Kazwala RR, Sadiki H, Roug A, Muse EA, Coppolillo PC, et al. Tuberculosis infection in wildlife from the Ruaha ecosystem Tanzania: implications for wildlife, domestic animals, and human health. Epidemiol Infect. 2013;141(7):1371-81.

6. Wilkie D. Bushmeat: a disease risk worth taking to put food on the table? Anim Conserv. 2006;9(4):370-1.

7. Wolfe ND, Daszak P, Kilpatrick AM, Burke DS. Bushmeat hunting deforestation, and prediction of zoonotic disease emergence. Emerg Infect Dis. 2005;11(12):1822-7.

8. Mbugi EV, Kayunze KA, Katale BZ, Kendall S, Good L, Kibik GS, et al. 'One health' infectious diseases surveillance in Tanzania: are we all on board the same flight? Onderstepoort J Vet Res. 2012;79(2):1-7.

9. John K, Kazwala R, Mfinanga GS. Knowledge of causes, clinical features and diagnosis of common zoonoses among medical practitioners in Tanzania. BMC Infect Dis. 2008:8:1-8.

10. Sambo M, Lembo T, Cleaveland S, Ferguson HM, Sikana L, Simon C, et al. Knowledge, attitudes and practices (KAP) about rabies prevention and control: a community survey in Tanzania. PLoS Negl Trop Dis. 2014; 8(12):e3310.

11. Mangesho PE, Neselle MO, Karimuribo ED, Mlangwa E, Queenan K, Mboera LEG, et al. Exploring local knowledge and perceptions on zoonoses among pastoralists in northern and eastern Tanzania. PLoS Negl Trop Dis. 2017; 11(2):e0005345.

12. Ntirandekura J, Matemba LE, Ngowi HA, Kimera SI, Karimuribo ED. Knowledge, perceptions and practices regarding brucellosis in pastoral communities of Kagera region in Tanzania. J Adv Vet Anim Res. 2018; 5(3):243-53.

13. Kioko J, Baker J, Shannon A, Kiffner C. Ethnoecological knowledge of ticks and treatment of tick-borne diseases among Maasai people in northern Tanzania. Vet World. 2015;8(6):755-62.

14. Stull JW, Peregrine AS, Sargeant JM, Weese JS. Household knowledge, attitudes and practices related to pet contact and associated zoonoses in Ontario, Canada. BMC Public Health. 2012;12:553.

15. Mfinanga SG, Mørkve O, Kazwala RR, Cleaveland S, Sharp JM, Shirima G, et al. The role of livestock keeping in tuberculosis trends in Arusha, Tanzania. Int J Tuberc Lung Dis. 2003;7(7):695-704.

16. Krentel A, Fischer $P$, Manoempil $P$, Supali T, Servais G, Rückert P. Using knowledge, attitudes and practice (KAP) surveys on lymphatic filariasis to prepare a health promotion campaign for mass drug administration in Alor District, Indonesia. Trop Med Int Heal. 2006;11:1731-40.

17. Yimer E, Mesfin A, Beyene M, Bekele A, Taye G, Zewdie B, et al. Study on knowledge, attitude and dog ownership patterns related to rabies prevention and control in Addis Ababa, Ethiopia. Ethiop Vet J. 2012; 16(2):27-39.

18. Dzikwi AA, Ibrahim AS, Umoh JU. Knowledge and practice about rabies among children receiving formal and informal education in Samaru, Zaria, Nigeria. Glob J Health Sci. 2012;4(5):132-9.

19. John K, Fitzpatrick J, French N, Kazwala R, Kambarage D, Mfinanga GS, et al. Quantifying risk factors for human brucellosis in rural northern Tanzania. PLoS One. 2010;5(4):e9968.

20. Mghamba J, Mboera L, Krekamoo W, Senkoro K, Rumisha S, Shayo E, et al. Challenges of implementing an integrated disease surveillance and response strategy using the current health management information system in Tanzania. Tanzan J Health Res. 2004;6(2):57-63.

21. CDC. Tanzania Surveillance (GHSA) in Action [Internet]. 2019 [cited 2019 Sep 19]. Available from: https://www.cdc.gov/globalhealth/security/stories/ tanzania-surveillance-ghsa-in-action.html

22. Prins HHT, Weyerhaeuser FJ. Epidemics in populations of wild ruminants: anthrax and impala, rinderpest and buffalo in Lake Manyara National Park, Tanzania. Oikos. 1987:49(1):28-38.

23. Mwakapeje ER, Høgset S, Fyumagwa R, Nonga HE, Mdegela RH, Skjerve E. Anthrax outbreaks in the humans - livestock and wildlife interface areas of northern Tanzania: a retrospective record review 2006-2016. BMC Public Health. 2018:18:106.

24. Hampson K, Lembo T, Bessell P, Auty H, Packer C, Halliday J, et al. Predictability of anthrax infection in the Serengeti, Tanzania. J Appl Ecol. 2011;48:1333-44.

25. Hampson K, Dushoff J, Cleaveland S, Haydon DT, Kaare M, Packer C, et al. Transmission dynamics and prospects for the elimination of canine rabies. PLoS Biol. 2009:7(3):0462-71.

26. Gascoyne SC, Laurenson MK, Lelo S, Borner M. Rabies in African wild dogs (Lycaon pictus) in the Serengeti region, Tanzania. J Wildl Dis. 1993;29(3): 396-402.

27. Fitzpatrick MC, Hampson K, Cleaveland S, Meyers LA, Townsend JP, Galvani AP. Potential for rabies control through dog vaccination in wildlifeabundant communities of Tanzania. PLoS One. 2012;6(8):e1796.

28. Cleaveland S, Fe EM, Kaare M, Coleman PG. Estimating human rabies mortality in the United Republic of Tanzania from dog bite injuries. Bull World Health Organ. 2002;80:304-10.

29. Mtui-Malamsha N, Sallu R, Mahiti GR, Mohamed H, OleNeselle M, Rubegwa $\mathrm{B}$, et al. Ecological and epidemiological findings associated with zoonotic rabies outbreaks and control in Moshi, Tanzania, 2017-2018. Int J Environ Res Public Health. 2019;16(6):2816.

30. Prins HHT. Nature conservation as an integral part of optimal land use in East Africa: the case of the Masai ecosystem of northern Tanzania. Biol Conserv. 1987:40(2):141-61.

31. Loth PE, Prins HHT. Spatial patterns of the landscape and vegetation of Lake Manyara National Park. ITC J. 1986;2:115-30. 
32. Lawi YQ. Where physical and ideological landscapes meet: landscape use and ecological knowledge in Irawq, northern Tanzania, 1920s-1950s. Int J Afr Hist Stud. 1999;32(2):281-310.

33. Kiffner C, Nagar S, Kollmar C, Kioko J. Wildlife species richness and densities in wildlife corridors of northern Tanzania. J Nat Conserv. 2016:31:29-37.

34. Kiffner C, Rheault H, Miller E, Scheetz T, Enriquez V, Swafford R, et al. Long term population dynamics in a multi-species assemblage of large herbivores in East Africa. Ecosphere. 2017;8(12):e02027.

35. Centers For Disease Control and Prevention. Rabies [Internet]. 2017 [cited 2018 Feb 15]. Available from: https://www.cdc.gov/rabies/

36. Centers For Disease Control and Prevention. Anthrax [Internet]. 2017 [cited 2018 Feb 15]. Available from: https://www.cdc.gov/anthrax/index.html

37. Centers For Disease Control and Prevention. Brucellosis [Internet]. 2017 [cited 2018 Feb 15]. Available from: https://www.cdc.gov/brucellosis/index.html

38. R Core Team. R: a language and environment for statistical computing [internet]. Vienna: R Foundation for statistical Computing; 2016. Available from: http://www.r-project.org/

39. Bates D, Maechler M, Bolker B, Walker S. Ime4: Linear mixed-effects models using Eigen and S4 [Internet]. 2015 [cited 2015 Oct 20]. Available from: http://cran.r-project.org/package=Ime4

40. Crawley MJ. Statistics: an introduction using R. Chichester: John Wiley \& Sons Ltd; 2005. p. 1-327.

41. Wei T, Simko V. R package "corrplot": Visualization of a Correlation Matrix (Version 0.84) [Internet]. 2017 [cited 2018 Jun 4]. Available from: https:// github.com/taiyun/corrplot

42. Dormann CF, Elith J, Bacher S, Buchmann C, Carl G, Carré G, et al. Collinearity: a review of methods to deal with it and a simulation study evaluating their performance. Ecography (Cop). 2013;36(1):27-46.

43. Gelman A, Su Y-S. Arm: data analysis using regression and multilevel/ hierarchical models. [Internet]. 2016 [cited 2018 Feb 15]. Available from: https://www.rdocumentation.org/packages/arm/versions/1.9-3

44. Bárton K. Model selection and model averaging based on information criteria (AICc and alike) [Internet]. 2013 [cited 2017 Dec 23]. Available from: https://cran.r-project.org/web/packages/MuMIn/index.html

45. Grueber CE, Nakagawa S, Laws RJ, Jamieson IG. Multimodel inference in ecology and evolution: challenges and solutions. J Evol Biol. 2011;24(4):699-711.

46. Richards SA. Dealing with overdispersed count data in applied ecology. J Appl Ecol. 2008;45(1):218-27.

47. Steenson R, Changalucha J, Steenson R, Grieve E, Cleaveland S, Lembo T. The need to improve access to rabies post-exposure vaccines: Lessons from Tanzania. Vaccine. 2018. https://doi.org/10.1016/j.vaccine.2018.08.086.

48. Regidor E, De Mateo S, Calle ME, Domínguez V. Educational level and mortality from infectious diseases. J Epidemiol Community Health. 2002;56(9):682-3.

49. Magnusson R. Controlling the spread of infectious diseases. In: Advancing the right to health: the vital role of law; 2017. p. 151-64.

50. Prins HHT, van der Jeugd HP. Herbivore population crashes and woodland structure in East Africa. J Ecol. 1993;81(2):305-14.

51. Kiffner C, Peters L, Stroming A, Kioko J. Bushmeat consumption in the Tarangire-Manyara, Tanzania. Trop Conserv Sci. 2015;8(2):318-32.

52. Mwakapeje ER, Høgset S, Softic A, Mghamba J, Nonga HE, Mdegela H, et al. Risk factors for human cutaneous anthrax outbreaks in the hotspot districts of northern Tanzania: an unmatched case - control study. R Soc Open Sci. 2018;5:180479

53. Kovacic V Tirados I, Esterhuizen J, Mangwiro CTN. We Remember. Elders Memories and Perceptions of Sleeping Sickness Control Interventions in West Nile. Uganda PLoS Negl Trop Dis. 2016;10(6):e0004745.

54. World Health Organization. The Control of Neglected Zoonotic Diseases: A route to poverty alleviation [Internet]. 2005 [cited 2018 Oct 9]. p. 54. Available from: http://www.who.int/zoonoses/Report_Sept06.pdf

55. Lankester FJ, Wouters PAWM, Czupryna A, Palmer GH, Mzimbiri I, Cleaveland $S$, et al. Thermotolerance of an inactivated rabies vaccine for dogs. Vaccine. 2016;34(46):5504-11

56. Bardosh K, Sambo M, Sikana L, Hampson K, Welburn SC. Eliminating rabies in Tanzania? Local understandings and responses to mass dog vaccination in Kilombero and Ulanga districts. PLoS Negl Trop Dis. 2014;8(6):e2935.

57. Bencin H, Kioko J, Kiffner C. Local people's perceptions of wildlife species in two distinct landscapes of northern Tanzania. J Nat Conserv. 2016;34:82-92.

58. Khorozyan I, Soofi M, Khaleghi Hamidi A, Ghoddousi A, Waltert M. Dissatisfaction with veterinary services is associated with leopard (Panthera pardus) predation on domestic animals. PLoS One. 2015;10:e0129221.
59. Ward DJ. The role of education in the prevention and control of infection: a review of the literature. Nurse Educ Today. 2011;31(1):9-17.

\section{Publisher's Note}

Springer Nature remains neutral with regard to jurisdictional claims in published maps and institutional affiliations.
Ready to submit your research? Choose BMC and benefit from:

- fast, convenient online submission

- thorough peer review by experienced researchers in your field

- rapid publication on acceptance

- support for research data, including large and complex data types

- gold Open Access which fosters wider collaboration and increased citations

- maximum visibility for your research: over $100 \mathrm{M}$ website views per year

At $\mathrm{BMC}$, research is always in progress.

Learn more biomedcentral.com/submissions 